\title{
"IF ON A WINTER'S NIGHT A REVELLER": \\ THE CLASSICAL INTERTEXT IN DONNA TARTT'S
}

\section{THE SECRET HISTORY}

\author{
(Part 1)
}

François Pauw, Dept. of Greek, University of Stellenbosch

\section{INTRODUCTION}

"Did I really want to spend my college career and subsequently my life looking at pictures of broken kouroi and poring over Greek particles?" (The Secret History, p.80).

The dilemma of Richard Papen, the narrator of American author Donna Tartt's 660-page debut novel The Secret History, is hardly typical of a modern best-selling thriller - but then Tartt's novel, although a best-seller, is not your average thriller. Like Eco's The Name of the Rose, it not only provides for suspense but also for class, having, as it does, a cast of students of the Classics and thus a classical field of reference. As my title, pace Calvino, suggests, Tartt's novel is fertilized with the cross-pollination of intertext. While at times being somewhat highbrow, it is nevertheless accessible to the educated non-classicist.

Its publication in September 1992 took the literary world by storm: not only did Knopf publishing house advance $\$ 450000$ for it - an unprecedented sum for a debut novel - but foreign rights were also sold to eleven countries for more than $\$ 500000$, with paperback rights adding a further half a million dollars.1 The Secret History had a first printing of $\mathbf{7 5}$ 000 copies, unheard of for a "literary" first novel. In addition, Alan J. Pakula bought the film rights for an undisclosed sum (Shapiro/Sawhill 1992:54). Since then, Tartt has also managed to win the Mekka Prize, awarded by Dutch and Flemish critics, for the best literary work of 1993.2

The reasons for the impact of Tartt's novel are manifold. Some have a bearing on the notso-hidden persona of the author: a petite, almost elfin, hard-drinking, chain-smoking convert to Catholicism, not averse to granting interviews, erudite to the point of ostentation (Kaplan 1992:248). Her denial of autobiographical echoes in The Secret History, and her elusiveness when pressed about her personal life, have enhanced rather than detracted from interest in her book.

In fact, in spite of her denial, there seem to be numerous similarities between her own student years at Bennington College - "a kind of omphalos of refined depravity, money and drugs and hormones and scholarship" (Kaplan 1992:279) - and the decadent pseudo-Ivy League elitism of Hampden College in Vermont, the fictional setting of her novel. In at least one passage homage is paid, implicitly, to her alma mater: it is surely no coincidence

1 Page references are based on the Penguin paperback edition (1993).

2 Cultureel Supplement NRC Handelsblad, 18.2.1994. 
that the newspaper the innkeeper at the Albemarle is depicted as reading is called "the Bennington Banner" (p.595). A further link is the consideration that she herself also studied Greek and Latin, like the six Classics students around whom her novel centres, although she admits that her characters are much more proficient in the languages than she is (Hunnewell 1992:3).

The ability of the author to memorize and quote poetry (Kaplan 1992:248) is reflected in the facility with which some of her characters quote extensively from Greek, Latin, French, Italian and English poets, while her acquaintance with world literature can be deduced from the innumerable allusions to literary topics, titles and authors - some, indeed, no more than name-dropping - made especially by her most intellectual character, the bibliophile polymath Henry Winter.

Critics (especially Vaill 1992:3) have pointed to parallels between Tartt's known idolization of T.S. Eliot, and implicit allusions to Eliot in The Secret History: in the dedication her editor is thanked for being il miglior fabbro ("the better craftsman") - the phrase Eliot borrowed from Dante in his dedication of The Waste Land to Ezra Pound; the name of Edmund ("Bunny") Corcoran, a character in the novel, recalls that of Edmund ("Bunny") Wilson, whose Axel's Castle contains one of the definitive critical appraisals of Eliot; and the name of the French professor at Hampden College, Georges Laforgue, reminds one of the French Symbolist poet, Jules Laforgue, an important influence on the early Eliot.

Moreover, Henry Winter comes from St. Louis, which was also Eliot's home town (p.59); the hotel where Henry and Camilla stay is called the Albemarle, which happens to be the name of the English Channel hotel where Eliot revised The Waste Land (Kaplan 1992:277). Tartt even picks up Eliot's technique of inserting quotations (e.g. before the Prologue; p.321; p.639) into her work (Allan 1992:65), and on occasion a whole passage from The Waste Land is quoted (pp.93-94).

Thus, the remark that Tartt "has a largish obsession, bordering on the cultic, with T.S. Eliot" (Kaplan 1992:250) does not appear to be exaggerated.

The author's erudition, as established in interviews and exemplified by such learned games, could account, in part, for the predominantly eulogistic reception of her novel. Other reasons for the impact of The Secret History, however, derive from the qualities of the novel itself.

\section{THE PLOT}

The Secret History is a title Tartt borrowed from the sixth century court historian Procopius' chronicles of the Byzantine emperor Justinian, because both books give accounts of a horrible reality underlying a facade of normality (Steinz 1992:1).3 Thus, incidentally, the author's acquaintance with things classical, and the possibility that the novel may be concerned with classical themes, are revealed to the discerning reader, by way of intertext, even before the first page is turned.

3 A further intertextual parallel is provided by a character in Balzac who uses the same phrase under comparable circumstances when he refers to "the secret History, where the true causes of events are, a shameful History" (Vautrin, the author's alter ego, commenting on the depravity of the times in Lost Illusions). 
The main body of the novel is indeed a "history" of sorts, in that the narrator recounts the events of one academic year in chronological sequence. But it is also reminiscent of Herodotean historie, in that the intellectual curiosity of the protagonists is the mainspring of action in the first section of the novel, while the investigative curiosity of outsiders threatens to expose the guilty secrets of the protagonists in the second part. Moreover, this "history" is "secret" in the sense that its suspense hinges on its potential for betraying secrets, for revealing the surreptitious, for exposing subterfuge and duplicity.

Nevertheless, it is no run-of-the-mill whodunnit: already in the prologue (pp.1-2) not only a murder is announced, but also the identity of both murdered ("Bunny") and murderers ("we"), as well as the location and nature of the murder. Kaplan (1992:250) aptly classifies it as "a murder mystery ... in which the only mystery is why - the who, what, when, and how all being known virtually from the word go". It is to Tartt's credit that she paces the novel well enough to ensure that some secrets remain undetected, and some codes undeciphered, till close to the end.

The narrator in The Secret History is Richard Papen, a bookish loner who recapitulates the events of some eight years previously (pp.5, 376) with a detachment innate to his personality and reinforced by the lapse of time. Richard recounts how, as a twenty-yearold Californian student of medicine, he broke away from the ennui of his working-class background to go and study Greek in the WASP-ish, imitation Ivy League Hampden College in Vermont. The atmosphere that Hampden evokes is redolent of John Irving, Robin Williams' Dead Poets' Society, and The Great Gatsby. In fact, in a despondent moment Richard explicitly perceives himself as belonging to the "tragic" world of Fitzgerald's main character (p.82).

At Hampden College, Richard, not without difficulty, manages to gain entry into the select course of a charismatic but eccentric (p.586) professor of Greek, Julian Morrow, where he meets a coterie of five elitist and somewhat pretentious students who are radically to change his life. At first they appear to be innocuously dilettante, albeit spoilt by their moneyed backgrounds (p.612), but as the novel progresses, their negative traits gradually become more marked.

The ringleader of this inseparable clique is the tall, rich and chillingly aloof Henry Winter, a polymath with not only a predilection for translating Paradise Lost into Latin verse in his spare time (p.95) and keeping a Latin diary (p.222), but also a talent, as it later turns out, for ruthless manipulation (pp.576-577). In contrast, Francis Abernathy, a dandified (p.19) hypochondriac (pp.98, 511-516) from Boston, appears rather effete. In the course of Richard's narrative, Francis gradually emerges from his gay closet (pp.256, 340, 540). His country house in the hills of Vermont, rather than his personality, will prove to be of importance to the plot (pp.86-119, 191-218). Edmund ("Bunny") Corcoran from Connecticut, the least cerebral of the group (pp.103, 123-125), exhibits a facade of hailfellow-well-met bonhomie, which soon proves to be obscuring a tendency toward sponging unabashedly (pp.66-69. 219-229) and even toward kleptomania (pp.126, 175, 419). Most irritating of all are his obnoxious hectoring and puerile garrulity (pp.178-181, 200, 206$218,304-306$ ). Camilla Macaulay, an ethereally beautiful orphan and the only woman in the group, is apparently not above incest with her twin brother Charles (pp.266, 536, 538). Richard, however, is irrevocably smitten by her (pp.112, 308-309, 519) and Henry later has a relationship with her (p.616). Charles, in turn, manifests a bibulousness which 
progressively deteriorates into full-scale dipsomania as his conscience, as well as fear of Henry, induces nightmares. 4

The above evaluation is coloured with the cynicism of hindsight. It should be stressed, therefore, that Richard's first response to this group of rich and gifted Classics students is one of awe. After his alienated adolescence in California he craves to belong, and now, it appears, he has found his niche: "I was surprised by how easily they managed to incorporate me into their cyclical, Byzantine existence. They were all so used to one another that I think they found me refreshing ..." (p.97). His temperament, however, would remain that of an outsider.

In spite of being accepted, Richard gradually realizes that all is not what it seems to be. His misgivings about the group's sinister nocturnal activities' are confirmed when he confronts Henry and the latter admits matter-of-factly that Charles, Camilla, Francis and he have unintentionally killed a man (p.191). In an attempt to attain a state of Dionysiac ecstasy - prompted by an academic discussion initiated by Julian Morrow - the four of them have, while in their Bacchic trance, unwittingly killed an innocent Vermont farmer. The passages in which their nocturnal frenzy is described6 represent the single most important classical motif in Tartt's novel, and will be discussed in detail in Part 2 of this article.

The last-minute omission of Bunny, mainly because of his loquacity, from the Dionysiac experiment caused him to remain unaware of the manslaughter until prying in Henry's diary (p.223). Armed with this knowledge, Bunny now increasingly embarrasses them with his infantile jibes (pp.179-181, 213-218). He not only threatens to expose them with his indiscreet blabbering, but conceivably might use his position to blackmail them, his motive being jealous schadenfreude rather than moral indignation (pp.224-225). To counter this new threat to their security, Henry starts masterminding schemes to dispose of Bunny. With a clinical aloofness Henry considers mushroom poisoning (pp.268-277, 294-295), but rejects it as too hazardous. When Bunny eventually becomes suspicious (pp.250-253) and actually confides in Richard that he fears for his life (pp.287-290), the Bacchanalian foursome, with Richard's tacit complicity, decides to act. They plan to push Bunny down a ravine, to create the impression of a hiking accident (pp.299-304). Book I ends with the execution of this plan.?

4 In fact, the other five protagonists are also at times depicted as drinking like Malcoim Lowry or Dylan Thomas, and most of them as smoking like Italo Svevo's autobiographical persona in Confessions of Zeno. On occasion, Richard even compares his own jitters and hallucinations to those of Ray Milland (the actor playing the role of the dipsomaniac central character, Don Bimam) in (Charles Jackson's sobering drinkalogue) The Lost Weekend (p. 348).

5 Implied by, e.g., excessive scratches and bruises, a strange preoccupation with the weather, loaded asides in Greek and Latin, mud-streaked linen, an apparent witches' brew in a copper cauldron (pp.105-107); Bunny's childishly taunting behaviour toward the group as a whole (pp.179-181), and particularly toward Henry (pp.153, 154); a muffled conversation between Henry and Francis overheard by Richard (pp.155-156); Bunny's vague admission to Richard that he distrusts Henry (pp.163-164).

6 Henry's description to Richard is recorded on pp.191-200; later Camilla complements it with what she remembers of the manslaughter (pp.422-423). Julian's initial discussion of "Plato's four divine madnesses" and "the terrible seduction of Dionysiac ritual" is described on pp.4047.

7 In fact, Bunny's death, like that of the farmer, occurs extra scaenam, as it were. Richard only narrates the events preceding Bunny's fall, with the actual murder scene implited by 
Thus, both murders - that of the farmer and, consequently, that of Bunny - occur in the course of Book I. In Dostoyevskyan terms, the crimes have now been committed; what follows in Book II is not detection, but the punishment embodied in the unremitting fear of detection. This punishment is mostly of a psychological nature and self-inflicted.

In this section Tartt makes use of a number of ruses to increase the reader's suspense, including various independent claims by minor characters to have seen Bunny, which all prove false. ${ }^{8}$ The tension builds up as the murderers' incogniti are threatened repeatedly with exposure. First, the manhunt lodged after Bunny's disappearance eventually succeeds in uncovering his body from under the snow (pp.435-436). Next, the two F.B.I. detectives summoned to Hampden appear ominously close to suspecting foul play (pp.400-404, 414$416,536-442$ ), in which case their investigation may reveal the identity of the five conspirators. Throughout, the possibility increases that the latter may be incriminated by their nervous guilt or by the hunches of people in whom Bunny might have confided (p.304).

Attending Bunny's funeral at the Corcoran home (pp.481-497), the contrite quintet is at a point of breakdown, and from then onwards most of the culprits try to stifle their guilt and escape from the private hell of their consciences by taking recourse to alcohol and drugs, thereby increasing the very real possibility that one of them might betray their guilt with a slip of the tongue. The behaviour of Charles, especially, now drinking uncontrollably, becomes a source of concern to the others.

The suspense reaches its zenith when a potentially lethal piece of evidence lands in Julian's possession - a delayed letter purported to have been written by Bunny before his death: "(Henry) is a fucking monster. He has killed a man and he wants to kill Me, too. ... Please help me" (pp.589-590). Julian initially regards it as a forgery by a crank, but eventually recognizes its authenticity, despite his students' desperate efforts to deter him from linking them to Bunny's death. Consequently, Julian resigns his post in dismay (p.608), but without betraying his students' secret.9

In the dénouement, events follow one another in quick succession. The characters have disintegrated: their guilty consciences, self- loathing, distrust and fear have deeply strained their friendship. Charles even fears that Henry might poison him with an overdose of drugs (pp.622, 625) lest he betray their secret while drunk. Eventually, the cool and

aposiopesis. The details of Bunny's death, and its aftermath, are supplied by way of haphazard flashbacks (pp. 1-2, 97, 267, 323-329, 333, 491, 495-496, 578) from the perspective of Richard as narrator.

8 Examples of such sidetracking mechanisms include the following:

(a) According to Bunny's girlfriend, Marion, Rika Thatheim saw Bunny outside First Vermont Bank on the Wednesday after Bunny's disappearance (p.353).

(b) Cloke Raybum speculates that Bunny could have been involved in drug dealing (p.359). The F.B.I. and the Press later investigate this suggestion (pp.415-420).

(c) A garage owner, Mr Hundy, claims to have seen Bunny in a car with two "out-of-towners" shortly after Bunny's disappearance (pp.387-388). This information, later (pp.428-432) exposed as untrue, temporarily sidetracks the authorities into considering kidnapping as a possibility.

9 Julian is also aware of the farmer's death (pp.282-283); he somehow condones it, however, as a sad but unforeseen consequence of the imponderables of a Bacchic experiment that was, after all, propagated by himself. 
collected Henry, somewhat unexpectedly, commits suicide (p.635), at which point Book II, and thus Richard's account of the year he spent at Hampden, is concluded.

In the epilogue Richard recounts how his guilt led to introversion and difficulties with sustaining relationships; his way of coping psychologically was to develop an interest in the moral world of the Jacobean dramatists, a world "of sin unpunished, of innocence destroyed" (p.645). Three years later, Richard recounts, Francis tried to commit suicide (p.647): after being caught out as being involved in a homosexual affair, he was forced to get married or forfeit his grandfather's inheritance. Charles was treated for his alcoholism, but ran away; despite Richard's infatuation with Camilla, she refuses marriage, because she still loves Henry. The book ends on a sombre note with a surrealist dream Richard has of Henry, and the reader knows that the images of the terrifying last moments of Henry, and of Bunny, will forever haunt the subconscious of the surviving foursome.

\section{ANALYSIS}

To the classicist, The Secret History is replete with a variety of literary allusions, particularly classical allusions and topoi. The basic framework of the plot (five university students involved in a double murder fear detection and experience guilt) does not essentially require a cast of students of the Classics, or classical allusions. One might argue that suspense could have been accomplished with equal effect if the characters had been, say, hard-drinking chemistry students (or plumbers) committing first accidental and then deliberate homicide. Instead of making numerous allusions to authors from Homer to Salman Rushdie, the characters could have interspersed their conversations with references to the Stock Market, reflections on American politics, or arguing the relative merits of two films, without detracting from the suspense.

One could even argue that Tartt might have reached a broader market by retaining the basic plot of murder, fear and guilt, but stripping it of highbrow elements. Why, then, her preference for depicting a group of elitist students, and why, even granted the arcane nature of their field of study, this proliferation of erudite allusions to classical authors, customs and morals? A novelist can, after all, become so highbrow as to alienate his readers, as was the case with the reception of Eco's esoteric Foucault's Pendulum.

Is Tartt suffering from the debutante syndrome of wanting to flaunt one's learning - even at the price of tedium? Although Rosenheim (1992:9), supported by Lescaze (1992:A12), denigrates Tartt's erudition as "a veneer of classical allusion", I have reason to prefer a less cynical interpretation. Assuming for the moment that the classical intertext plays a significant role in her novel, I want to examine three questions: the nature of her imitatio, strategies employed for integrating the Classics into the plot, and the moral significance of such a literary ploy. These questions should prove to be stimulating not only to dyed-inthe-wool classicists, but also to anyone with an interest in intertext, subtext, and comparative literature in general.

\section{IMITATIO AND INTERTEXT}

The adaptation of classical originals to a modern idiom is nothing new: it represents the very concept of mimesis so abhorrent, for ideological reasons, to Plato (especially Rep. $376 \mathrm{e}-398 \mathrm{~b}, 595 \mathrm{a}-608 \mathrm{~b}$ ) and so lauded, as imitatio, by the Romans (e.g. Cicero De Or. I 260, Il 90-92; Quintilian II xiii. 8; Horace A.P. 133-135, 240-242). 
Essentially, there are four options available to a modern author "copying" or adapting the Classics. These are: using a Greek or Roman original in a given genre (whether drama, 10 as often, or other genres) 11 as a source for a modern adaptation within that genre; secondly, adapting a classical original to a different genre;12 thirdly, using a historical or biographical novel to portray a particular period or historical personage; 13 fourthly, writing a novel or poem which contains general allusions to things classical without owing allegiance to any single magnum opus. 14

Of the strategies mentioned, Tartt employs the second (in that she borrows the atmosphere, moral framework, and part of the plot of a Greek tragedy - Euripides' Bacchae - as an important subtext of her novel) and the fourth (in that her novel, featuring students of the Classics, naturally contains discussions of and references to classical texts, themes, and personages). Thus the classical intertext still echoes in the late twentieth century.

It may be noted in passing that the nature of intertextual mimesis has received much critical attention, especially in the past two decades. "Echoes", as used above, is an auditory metaphor for the diachronic interplay between different texts; visual metaphors, however, appear to be particularly popular in the parlance of intertextual theory. 15 Foster (1994:111), for instance, appropriating the vocabulary of Kearney, acknowledges three diachronically and hermeneutically distinct metaphors for representation; these metaphors are also applicable to intertext:

(a) the mirror (a premodern paradigm of mimesis, symbolizing a "reflection" of sociocultural, political or psychological "reality");

(b) the lamp (an emblem of the modern productive imagination); and

10 For example, Racine, in his Phèdre, adapts the plot and characters of Euripides' Hippolytus and Seneca's Phaedra; André P. Brink borrows from Plautus' Menaechmi (via Shakespeare's The Comedy of Errors) in writing Kinkels in die Kabel. Sometimes the correspondence between "original" and "copy" may be rather tenuous, as in T.S. Eliot's plays The Confidential Clerk, The Cockail Party and The Family Reunion, from which it cannot readily be deduced that they are derived from Euripides and Aeschylus, respectively.

11 Dante, for example, uses Vergil as a model for his Divina Commedia; Dr. Johnson adapts Juvenal's Tenth Sarire to suit his purpose.

12 Thornton Wilder's novelette The Woman of Andros, as an adaptation of Terence's eponymous comedy, is a case in point. Christoph Ransmeyr's quaint magic-realism evocation of Ovid's Metamorphoses in his novel The Last World probably also belongs in this category.

13 Here examples abound, ranging from the painstaking research of Colleen McCullough (The First Man in Rome, The Grass Crown) to the Claudius novels of Robert Graves, Margaret Yourcenar's The Memoirs of Hudrian, and the popular novels of Mary Renault and Rosemary Sutcliff.

14 Post-Renaissance prose and poetry abound with examples belonging to this category: cf. G. Highet 1967: The Classical Tradition.

15 For a tactile or "plastic" metaphor, see Brink 1989:38, who applies it to fictionality in general: "... die fiksie [is] nie ' $n$ lineêre of 'natuurlike' voortsetting (of produk) van die sg. buitenste werklikheid ... nie; [dit is] nie sonder meer ' $n$ afkaatsing of nabootsing daarvan nie, maar 'n maaksel, ' $n$ fabrikasie, ' $n$ vormgewing. Die woord 'fiksie' is immers afgelei uit die Latyn fingere: om te maak, te fatsoeneer, te boetseer, vorm te gee ...". 
(c) the labyrinth, or hall of mirrors, or hologram (a symbol of the postmodernist consciousness). 16

To the latter, Foster (1994:116) adds the computer, as emblematic of an ephemeral discourse with the postmodernist potential to undermine the master narrative via, inter alia, montage and pastiche.

The metaphor I find most effective for denoting postmodern representation, however, is that of the library, suggested by Van Boheemen (1981:123): "een bibliotheek waarin alles wat ooit geschreven, ja zelfs gedacht is, is bewaard".17

Although Tartt avails herself of surprisingly few of the narratological artifices associated with postmodernist artisanship, and the evaluation of such tricks is not my primary concern, the metaphor of a library is eminently applicable to her use of intertextual mimesis in a "bookish" novel such as The Secret History. If it is generally true that "meaning" can be "produced" in any text by considering its "difference" with another text (Van Boheemen 1981:126), then this should be all the more valid in the case of a novel with innumerable explicit literary allusions to identifiable sources. One could imagine the world of Tartt's novel as one vast library in which different texts from different genres and eras are in continuous dialogue with one another, a sotto voce buzz of literary exchange enriching the whole corpus of existing texts. This also has implications for the perspective of the reader: "the whole body of literature is available, at least potentially, when a new literary artefact is being encoded by a writer or decoded by a reader" (Ruthroff, quoted by Brink 1989:29).

One could contend that The Secret History, though formally a novel, does actually have a number of characteristics in common with tragedy as genre. The narrative has tragic overtones from the very first page of the prologue, where Richard describes the aftermath of Bunny's death. His initial tone appears matter-of-fact, but the first sentence of Book I actually refers to Aristotelian hamartic, 18 thus preparing the reader for a moral and psychological framework reminiscent of Greek tragedy. The formal structure of the novel also echoes Greek tragedy, in that it contains an expository prologue (pp.1-2) and a retrospective epilogue (pp.637-660), separated by two lengthy "episodes" (Book I and Book II). The detached comments of the narrator (i.e. his Platonic haple diegesis, 19 as

16 For comparable visual metaphors, see Viljoen 1988:351-358.

17 Van Boheemen obviously uses the term "library" as no more than a metaphor for intertextual cross-pollination. In one famous instance of literary allusion, however, libraries also serve - in addition to this meta-function - as a constitutive feature of a novel, as a fictionally indispensable datum for the development of its plot and theme. The novel in question is Umberto Eco's The Name of the Rose, where the monastic library (which, of course, also happens to be a labyrinth) has fictional predecessors in the texts of the Argentinian author Jorge Luis Borges. Eco pays literary homage to Borges by not only transparently naming the blind librarian in the Italian monastery, Jorge de Burgos, after him, but also borrowing classical Borgesian motifs such as labyrinthine libraries, mirrors, detectives, and books about books (Corry 1992:427).

18 "Does such a thing as 'the fatal flaw', that showy dark crack running down the middle of a life, exist outside literature?" (p.5).

19 Rep. 392d, where it is contrasted with mimesis, the former implying first-person narrative, the latter dramatic speeches or "impersonation". See further De Jong 1987:2-5; Cilliers 1986a:4-8; Genette 1981:66-69, 76-77, 84-85. 
distinguished from narrated dialogue) could perhaps be interpreted as resembling a Euripidean "spectator-chorus" in function. Moreover, the pseudo-Aristotelian unities of time (one academic year), place (Hampden College and surrounding Vermont) and action (the cause and effect of Bunny's murder) entrenched by Castelvetro are also maintained, albeit unfettered by dramatic economy.

A further resemblance between Greek tragedy and a tragic novel such as The Secret History is to be found in the function of antinomies and discrepancies, according to psychological-anthropological structuralist criticism, in tragedy. What critics like Vernant have identified as a pivotal function of tragedy, is remarkably applicable to the social and moral order in The Secret History. Vernant stresses the role of tragedy as "the field of the problematical, the area where the familiar institutions are called into question and the moral vocabulary, no longer adequate, becomes ambiguous or self-contradictory" (Segal 1986:44). Tartt's novel, although for the most part devoid of the ritualistic or institutional concerns Vernant's thesis depends on, appears to share this trait with tragedy.

On occasion, the authorial persona even seems to play postmodern ventriloquist with her characters, much like Calvino or Julian Barnes, so as to remind the reader of the dramatic nature of her material. Thus Richard, in describing the surprisingly limited impact the manslaughter had on their psyches, resorts to a theatrical metaphor: "Monstrous as it was, the corpse itself seemed little more than a prop, something brought out in the dark by stagehands and laid at Henry's feet, to be discovered when the lights came up" (p.248). After Bunny's disappearance, Tartt employs a character to indulge in some metafiction. Richard imagines him and his friends as actors: "If this was a movie, we'd all be fidgeting and acting really suspicious" (p.385). A similar narratological game is played when Julian rather conspicuously remarks: "Life has got awfully dramatic all of a sudden, hasn't it? Just like a fiction..." (p.411). Shortly afterwards, in describing the studied carelessness employed by Henry in response to the F.B.I. men's inquiries, Richard pointedly adds: "... he had waited in the wings a long while for this moment, when he could step onto the stage and assume the role he'd written for himself ..." (p.414). Against the background of Bunny's death, Richard describes him as "an old familiar jokester cast ... in the tragic role" (p.448). In similar vein, after Julian's identification of Bunny's letter, Richard remarks on the former's personality change: "It was as if the charming theatrical curtain had dropped away and I saw him for the first time as he really was: not the benign old sage, the indulgent and protective good-parent of my dreams ..." (p.602). The use of such Thespian metaphors further substantiates the view that Tartt's work can be read as a Greek tragedy in novel form.

But most importantly, the ineluctability of fate, and the fact that hubris is inexorably followed by nemesis, overshadow the whole elaborate second part of the novel, where the youthful arrogance of the protagonists is punished by emotions and events which, on a psychological level, are no less gruesome than the punishment meted out to Pentheus in The Bacchae. In fact, the psychological disintegration of the five guilty students is probably even more excruciating than the physical dismemberment of Pentheus: the latter's gory demise is a Procrustean operation with a terminus, whereas the suffering of Richard and his friends has a Sisyphean quality to it.

It can be concluded, then, that Tart is blending different traditions of post-Renaissance imitatio to create a novel in which the Classics play a major role. Moreover, as a novel, it contains a number of characteristics that originated with Greek tragedy as genre. 


\section{STRATEGIES}

The second question to be examined pertains to strategies employed by Tartt for integrating the Classics into her novel.

As an obvious starting point we may note that Tartt's protagonists happen to be students of classical Greek. (Although all but Richard have a Latin background, and fairly often refer to Latin topics or quotations, the course offered by Julian in the academic year described is theoretically limited to Greek (p.33).)

Tartt's proclivity for erudite literary allusions could have been plausibly satisfied had they been modern language students, or students of comparative literature: the text abounds with references to post-classical literature. 20

At first glance, such a Who's Who of titles and authors may look embarrassingly like mere exhibitionism. However, as it is spread over 660 pages, such ostentatiousness rarely impedes the flow of the narrative or plot development - no more, at least, than is the case with established "intellectual" novelists like Bellow, Burgess and Rushdie. The assumption that frequency of allusion reflects Tartt's erudition, does not necessarily preclude the possibility that her allusions may also be thematically functional. They are used either by the authorial persona, as "liminal" quotations between sections, 21 or by the narrator, in reporting conversations and in describing and evaluating events. Here the atmosphere has to be fairly highbrow: students of the Classics do tend, on the whole, to be bibliophiles, and in Henry's case it is stressed at the outset (p.20) that he is an unusually well-read polyglot. Moreover, a number of Henry's classmates study English or French, which would broaden their literary field of reference.

Thus it could be argued that the author achieves consistency of atmosphere by interspersing the dialogue with literary allusions, mostly as a natural manifestation of an intellectual character's train of thought. Moreover, they serve a number of diverse purposes, as can be seen from the following categories: oral quotations from poetry or prose;22 drama production;23 academic courses and assignments;24 dreams;25 the acquisi-

20 See Addendum 1 (p.161).

21 E.g. those from Nietzsche and Plato (before Prologue), Dodds (p.321) and Ford.(p.639).

22 After buying an ancient greyhound, Henry quotes long passages about Emma Bovary and her greyhound in the original (p.99); at Bunny's funeral Henry reads a favourite poem of the deceased, Housman's With Rue My Heart is Laden (pp.488-489).

23 An acquaintance of Richard, Judy Poovey, refers to the preparation of costumes for As You Like It (p.54).

24 A panic-stricken Bunny has to write a paper on John Donne (p.123); the lecturers offering courses on Steme, Defoe, Marx and Castaneda terminate their use of drugs in public on account of police intervention (p.545); Richard writes his thesis on Jacobean dramatists like Marlowe and Tourneur (pp.645-646).

25 Literary figures even invade Richard's subconscious when he dreams about looking for the grave of Marcel Proust or George Sand (p.501); later, a feverish Charles has a dream in which Dante features (p.561). 
tion, possession, perusal or donation of books;26 translations;27 anecdotal or biographical memorabilia; 28 comparison or identification with authors or literary characters. 29

Allusions to post-classical works are not scattered at random, but consistently attributed to certain characters rather than others. Thus they are more often employed by Henry, Richard and Francis than by the twins. Since Bunny's interest in the written word seems to be limited to trivia such as The Bride of Fu Manchu (p.103), or "some corny old Lawyer's Joke Book" (p.181), Tartt refrains from encumbering him with literary allusions. 30

A near to total absence of allusions to German literature, in contrast with Anglo-American, French and classical literature, is conspicuous. This could be a reflection of the implicit author's predilection or limitations, or it could simply be interpreted as commensurate with her characters' un-Germanic academic background.

The absence of allusions to authors or novels of the two decades preceding Tartt's novel, barring Salman Rushdie (p.610) and Carlos Castaneda (p.545), represents a more puzzling lacuna. In a novel published in 1992, and parading protagonists who are generally wellread and not averse to literary allusion, one would have expected at least some mention of, say, magic realism. That Jeanette Winterson or Vikram Seth is not yet mentioned, is understandable. One searches in vain, however, for the names of Grass, Eco, Calvino, Isabel Allende, García Márquez, Vargas Llosa, Carlos Fuentes, Julian Barnes or Milan Kundera. This omission may represent a conscious ploy on the author's part to highlight the antiquarian and antiquated nature of the world of Julian and his students. They seem to live in a time-warp where the boundaries of the canonical in post-classical literature are dictated by a conservative corpus somewhere between Dante and Sylvia Plath. This dated value-scale, in turn, represents a backdrop against which allusions to the Graeco-Roman Classics would acquire more credence.

In this way, Tartt attempts to bolster the perception that the microcosm in which Richard and his friends live, is out of touch with modern reality. Other considerations confirm this view: with the exception of Bunny (pp.377, 487-488), they do not seem to have any interest in sport; they seldom go to the cinema and rarely watch television (p.385); for students, they have remarkably fixed habits (p.97); they are hardly involved in long-term

26 In Francis' country house historic editions of Ivanhoe and Byron's Marino Faliero are stored (p.89); Francis buys a biography of Cortés and a translation of Gregory of Tours (p.504); Bunny presents Richard with a copy of the poems of Rupert Brooke (p.126); Richard develops a headache from reading Hegel (p.146); Richard presents Charles with a couple of P.G. Wodehouse paperbacks (p.564); Francis reads St. Simon's Mémoires in French (p. 108); Richard peruses Proust in the aftermath of Henry's suicide (p.642); Richard reads Our Mutual Friend to Francis on his hospital bed (p.649).

27 Henry attempts a translation of Paradise Lost into Latin verse (p.95); Bunny buys a copy of Dorothy Sayers' translation of Inferno with a view to his Italian trip (p.121).

28 Julian is said to have been acquainted with, or befriended by, a number of literary figures, including Ezra Pound (p.17), the Sitwells and T.S. Eliot (p.148), Gertrude Stein (p.282), George Orwell (p.605); Henry recalls that Dickens used to stay in the Parker House in Boston (p.189): Richard mentions that Rudyard Kipling used to stay in the Albemarle Inn (p.594); Richard criticizes Tolstoy for having boasted that he had killed a man (p.599).

29 See Addendum 2 (p.161).

30 Since most of the characters would be unacquainted with or not interested in pulp writers, the latter receive scant reference. Cf. Raymond Chandler (pp.161-162); "one of those paranoia books by Philip K. Dick" (p.417). 
relationships. The absence of the present, to deconstruct Derrida, presents us with the past. Especially Henry lives in a time-warp: he seems to be unaware that a man has landed on the moon (p.98), although he published a translation of Anacreon, with commentary, when he was only eighteen (p.20), is busy with the translation of Paradise Lost into Latin (p.95), and is capable of speaking with authority on Sanskrit or Coptic (pp.58, 447), hieroglyphics (p.59), ornithomancy (p.72), and a whole range of other esoteric subjects.31

To counter the classical clique's antiquated frame of reference, Tartt portrays Hampden campus as very much pirt of the late twentieth century. Outside Julian's Lyceum, the socio-cultural fiction created by Tartt reflects a reality that is ephemeral rather than esoteric, quotidian rather than classical. The schism between the "otherworldliness" of the protagonists and the "with-it" world of their more mundane fellow-students is highlighted by an abundance of chronological clues and pointers which may aid the dating of Tartt's fictional creation. These clues could be listed in the following diachronic sequence:

(a) The students at Hampden, not excluding the holier-than-thou protagonists, at times seem to have access to a pharmaceutical cornucopia. The extent of drug abuse on campus (see especially pp.254, 417-418, 426, 475-476) seems to preclude a dating prior to, say, Haight-Ashbury or Woodstock (c.1968-1969). 32

(b) A number of explicit references make it clear that the narrator has a retrospective view of the nineteen-seventies, ${ }^{33}$ which would make the early nineteen-eighties a terminus post quem for the fictional world of The Secret History.

(c) This deduction is substantiated by allusions to politics and politicians. Although some allusions are vague (Saddam Hussein: p.431; Golda Meir: p.441) and others inaccurate (Carter's 1975 presidency: p.431), ${ }^{34}$ an important clue is provided by a reference to the assassination of Egyptian president Anwar-el-Sadat in 1982 (p.441). ${ }^{35}$ This is the most recent definite date mentioned in the novel. 36

31 This includes the Catuvellauni, late Byzantine painting, or headhunting in the Solomon Islands (p.93); Arabic (p.276); Theravadic vipassana (p.331); Tantrism (p.447), and rare rose species (p.582).

32 In fact, apart from general references to nun-of-the-mill amphetamines, barbiturates and hallucinogens, mention is also made of the designer drug Ecstasy (p.418). This neologism was unknown before 1986 (Green 1993:83).

33 E.g. "Playboy magazines from the 1970s" (p.131); "an ugly 1970s building" (p.186); "a road movie from the early seventies" (p.349).

34 In 1975 Gerald Ford was still president of the U.S.A. Carter was elected as the 39th president of the U.S.A. on 2 November 1976 (Beal \& Grisewood 1990:53).

It is tempting to ascribe such historical inaccuracies to Tartt as authorial persona, but the reference to 1975 is made by a fictional character, the excited William Hundy.

35 Once again, the date mentioned by Agent Davenport is slightly inaccurate: in actual fact Sadat was assassinated on 6 October 1981 (Beal \& Grisewood 1990:59).

36 Of interest is also F.B.I. agent Davenport's reference to mass murderer Morris Lee Harden "back in '78", to which his colleague Sciola replies: "These kids don't remember Morris. ... That was before their time" (p.441). Note that specific dates such as 1975 or 1982 are not mentioned by Richard or his friends (which would have been out of character), but by $\mathrm{Mr}$ Hundy and Agent Davenport, who represent an establishment thinking in linear terms. 
(d) Allusions to socio-cultural trends manifested in, and personalities associated with, inter alia, fashion, art, the cinema, television and pop music, collectively point to yet a later date (1986). 37

(e) The most recent date unambiguously implied by the text of The Secret History, however, is 1989, a date that can be checked against the intertext of recent literary politics. When the Dean of Studies has to explain Julian's sudden absence, he mentions "the Isrami government" in vague terms, but then proceeds to describe Julian as "Hampden's own Salmin Rushdie" (p.610).38 This can only pertain to the fatwa the ecclesiastical government of Iran decreed against Rushdie on 14 February 1989 (Beal \& Grisewood 1990:63) in response to the 1988 publication of The Satanic Verses, so that 1989 becomes a plausible terminus post quem for the fictional world of Tartt's novel.39

Thus the "otherworldly" microcosm of the six protagonists is offset by the reminder that there is also a "real" world, inhabited by "normal" students, whether "postmodern" or "pre-postmodern", 40 as if to highlight the esoteric, arcane nature of classical studies by way of contrast.

The fact that Richard and his classmates are students of Greek, has far-reaching implications for the intensity of their interaction with one another, and their relative lack of contact with the rest of the student body: Julian Morrow's course is, by its very nature and by virtue of Julian's aristocratic bent, shown as elitist; geographically as well as intellectually, it is cut off from the rest of the campus. In fact, when Richard wishes to gain entrance into Julian's course, he is told that Julian "conducts the selection on a personal rather than academic basis" (p.13), normally limiting his class to only five students (p.17). His classroom is variously described as "the Lyceum" (p.15), "some sort of Platonic microcosm of what he thought a classroom should be" (p.35), and (sarcastically) "the Inner Sanctum ... The Holy of Holies" (pp.607-608). Julian's world reminds one of a quaint little verse of unknown origin: "When eras die their legacies are watched by strange police, / And professors in New England guard the glory that was Greece."

37 Note especially "diabolical rap music" (p.290; cf. p.446) and a "laptop" computer (p.414). The words "rap" (as applied to a genre of pop music) and "laptop" are neologisms coined in 1985 and 1986 respectively (Green 1993:146, 227).

38 This remark is clarified in a previous passage with a bearing on the fictitious state of Isrami (pp.411-412), where Julian's role as tutor to the exiled Isrami crown princess is described. Terms used in that passage ("a dynasty (which) traced its origins to the Tower of Babel", "revolution", "terrorist state", "terrified of assassins" and, especially, "Isramic jihad") leave little doubt about the actual country which served as a model for this piece of fiction.

A new intertextual twist has recently been added to the Rushdie saga when John Irving dedicated his latest novel, A Son of the Circus, to Salman Rushdie (Steinz 1994:3). The resemblances, by coincidence(?), between Irving's murder plot and that of Tart are overshadowed by the resemblances, by design, between Irving's main character and Rushdie himself.

In fact, the date 1989 as terminus post quem accords with extra-textual evidence: the Brat-pack writer Bret Easton Ellis, a friend and classmate of Tart (and misspelt co-dedicatee of her novel), "had been reading the novel, as it progressed, for six years, since he and Tartt were in their second year at College". That was in 1983 (Kaplan 1992:250, 276).

40 This litotic phrase is to be found in the inimitable P.J. O' Rourke (Give War a Chance, Picador 1992). 
Julian's seniority, temperament and charming phraseology imbue him with an aura of authority that blends well with his vast learning, and that would have been less convincing in a much younger tutor. ${ }^{41}$ Nevertheless, his teaching methods are regarded as unusual, if not downright idiosyncratic, by some of his colleagues (pp.14-15, 608). Not all senior academics share his enthusiasm for the Classics: on occasion the Dean of Admission, while in his cups, confides in Richard that Classics consist of "wars and homos" (p.61).

The dimunitive size of the Greek class at Hampden exposes the coterie of six students to potentially unhealthy in-breeding that has not only academic, but also social ramifications. The fact that they are perforce next to inseparable facilitates the arrangements for the nocturnal Dionysiac experiment conducted by four of them, but also facilitates detection by the two odd-men-out, Bunny and Richard. In Book II of the novel, however, the physical proximity of the five remaining members becomes a threat to the stability of their friendship as various forms of guilt and distrust play havoc with their emotions: the Sartrean l'enfer est l'autre becomes a grim reality (cf. p.544).

Considering the elitist nature of Julian's course, and the enthusiasm and talent of most of his students, 42 it comes as a surprise to note the haphazard nature of the motives that initially drew some of them to the Classics. Richard's consideration was mere laziness: while still in California, he chose the Greek course for the simple reason that Greek classes happened to meet in the afternoon, allowing him to sleep late on Mondays (p.8). Henry's love of reading, and thus his wide field of reference (although not necessarily his interest in the Classics), could be traced back to a childhood car accident as a result of which he was immobilized and confined to bed for a long period (p.60). In the case of Bunny, conspicuously dyslexic and spectacularly devoid of intellectual prowess, if not pretentions, something more outlandish is called for to account for his choice of subject. Tartt furnishes an ingenious explanation: "... Greek had been a mandatory course of therapy, his prep school having theorized it was good to force dyslexic students to study languages like Greek, Hebrew and Russian, which did not utilize the Roman alphabet" (p.108). The fortuitous nature of these choices appears to be deliberately linked to an important leitmotif to be discussed in Part 2 of this article, that of the caprice of Fate versus controlled decision-making.

\section{TARTT'S RANGE OF ALLUSION}

Thus Tartt creates an atmosphere in which allusions to things classical would come naturally. She succeeds in plausibly portraying allusions to the Classics on a variety of levels. The following categories may be distinguished: grammar and academic assignments; lexicography; classical scholars; spoken or written Greek and Latin; classical authors and topoi.

\subsection{Academic assignments}

To lend credence to the atmosphere of undergraduates struggling with the morphological and syntactical intricacies of a complex language, Tartt frequently provides occasion for her characters to refer to aspects of their studies. For example, when Bunny is,

41 Julian's successor, the naive and inexperienced Dick Spence, acts as a foil to him, even if somewhat caricatured (pp.615-616).

42 They do have academic limitations, though, as witness Richard's evaluation on p.264. 
predictably, out of his depth in finding the correct case to express "motion towards",43 Richard, as newcomer, establishes his bona fides by suggesting the locative suffix (pp.2122). Henry displays his customary one-upmanship by denigrating Richard's solution as "grammatically correct but perhaps a bit off contextually" (pp.24-25).44

Greek Prose Composition is still adhered to, as Richard discovers the hard way; on occasion finishing these assignments in time necessitates plagiarism. Richard recounts how he had to write a two-page essay, in Greek, on any epigram of Callimachus; he notes, quite correctly, that merely translating an essay written in English into Greek is pedagogically invalid, but "if done properly, off the top of one's head, it taught one to think in Greek" (p.234). On a later occasion he resorts to copying Francis' Greek homework (p.342) - not surprisingly, in view of his assessment that "... Greek grammar and prose composition ... was brutal, bludgeoning labor" (p.80), or that it was "coolie labor" when compared to "the easy delights" of English literature (p.264). Of pedagogical interest is the following depressingly recognizable non sequitur copied by Richard from Charles' Prose Composition homework: "Being weary from the march, the soldiers stopped to offer sacrifices at the temple. I came back from that country and said that I had seen the Gorgon, but it did not make me a stone" (p.343). Is such a semantic hiatus merely intended to expose Charles' hermeneutic incompetence, or does it actually reflect Tartt's view of what Greek Prose Composition should be all about? If the latter, it appears terribly outdated.

Other pedagogical matters sounding all too familiar include translation into English;45 grammatical niceties; 46 etymology; 47 burning the midnight oil (p.82); inability to study constructively; 48 technological aids; 49 methods of examination (pp.608-609); the future of the Classics; 50 mnemonics as a pedagogical aid. 51

43 "... you know what I mean. Aorist, ablative, all the same thing, really" (p.22). At this point Bunny becomes a caricature rather than a plausible character.

44 Against the background of Henry's pedantry, it is surprising that he fails to distinguish between the actual locative ending $\left(-\theta_{l}\right)$ and $-\zeta \epsilon$, which expresses motion towards (Smyth 1956:99 par. 342: "place whither").

45 Richard has to translate a Pindaric ode (p.159).

46 Particles (p.80); the second aorist (p.170); the optative versus the subjunctive (p.240); the social implications of gender (p.264); the resemblance between tulips and the Greek letter psi (p.344).

47 After discovenng Henry's one-way flight booking to Argentina, Richard, with deconstructionist irony, attempts a naive etymologization of that country's name: $A R=$ gold, GEN $=$ birth, TINA $=$ who? $(p \cdot 176)$.

48 Struggling to read the Parmenides in the throes of a hangover, Richard experiences the text as "... indecipherable, bird footprints on sand" (p.70); after Bunny's death Richard experiences a mental block while attempting to study: "... my noun cases, my verb forms, had left me utterly" (pp.372-373).

49 Richard explains the peculiarities of a Greek typewriter (p.588).

so After Julian's sudden resignation, the Dean of Studies mentions the likelihood of the Classics being phased out at Hampden (p.609).

51 To the embarrassment of the students, their new tutor employs ridiculously naive mnemonics: "Agathon. Do you know how I remember that word? 'Agatha Christie writes good mysteries." " (p.615). 
One passage which has a bearing on syntax, warrants special mention: in the epilogue (p.642) Richard thinks back, inter alia, to the first sentence he ever learned in Greek: $\mathrm{X} \alpha \lambda \epsilon \pi \dot{\alpha} \tau \dot{\alpha} \kappa \alpha \lambda \dot{\alpha}$ ("Beauty is harsh"). In this case it constitutes more than a mere syntactical excercise: it also embodies a reflection upon one of the main tragic topoi of Tartt's novel, viz. the enchanting but destructive power of naked emotion, stripped of any semblance of rationality and order.52

On the whole the examples quoted play a functional role in portraying the academic world of the Greek student, without contributing anything of importance to the plot; serving to put the stamp of authenticity on the scholarly world of Richard and his fellow-students, without being otiose.

\subsection{Lexicography}

There is one example, though, that merits further scrutiny; it is exceptional in that it does not merely lend credence to the world of Greek studies, but actually provides an impetus that proves pivotal to the development of the plot. Any portrayal of classical Greek studies would sound less authentic without reference to the indispensable Liddell \& Scott. Richard has occasion to refer to this ubiquitous dictionary more than once (pp.79, 159, 166-167, 566) as a lexical aid. At a juncture in the novel where Richard starts harbouring suspicions about his classmates, and especially Henry, being involved in something clandestine, he visits Henry's flat in his absence in search of a borrowed Liddell \& Scott. Richard finds the lexicon, but also, next to it, a flight reservation with a telephone number. Upon dialling the airport's booking office, he learns that a reservation for four one-way tickets to Buenos Aires has been made in the name of one Henry Winter (pp.166-169). Armed with this information, the flabbergasted Richard, now sure that something serious is amiss, is able to confront Henry, as a result of which he becomes privy to the killing of the Vermont farmer (pp.187-200). Only much later, after Bunny's death, is Richard able to deduce that the whole sequence of events, commencing with the misplaced dictionary adjacent to the flight numbers, could have been surreptitiously engineered by Henry, in order to lure him in as an unwitting accomplice (pp.576-578).

Thus Tartt manages to utilize an everyday tool of Greek studies - the lexicon - as an instrument indispensable to the development of the plot of her novel.

\subsection{Scholarship}

To lend further credence to Tartt's depiction of Greek studies, her characters on occasion refer to actual Greek scholars. Thus Bunny, in the course of a symposion with Richard at a restaurant, proposes a toast to Periclean Athens and (the Platonic scholar) Benjamin Jowett (p.64); later Charles mentions (the translator) Richard Lattimore in a tone of implied awe (p.616). These two examples have no bearing on the plot, but merely serve, en passant, to render authentic the portrayal of the students at Julian's Lyceum.

A third example, however, serves a different purpose: after Bunny's murder can be deduced to have taken place, Tartt inserts a quotation from E.R. Dodds at the commencement of Book II (p.321). It is taken from Dodds' authoritative The Greeks and

52 In Julian's seminal lecture on the Dionysiac, he introduces his students to the irrational aspect of the Greeks (à la Dodds). Richard is so awe-struck that he writes in his diary: Beauty is terror (pp.46-47). 
the Irrational (1973:77) and reads as follows: "Dionysus is the Master of Illusions, who could make a vine grow out of a ship's plank, and in general enable his votaries to see the world as the world's not." This extract reflects an important leitmotif of the novel, viz. the contrast between the Apollinian (reality: lucid, overt) and the Dionysian (illusion: opaque, covert). After Bunny's death, the five conspirators attempt to hide behind a facade of normality. The insidious effects of alcohol and drugs provide but an illusionary respite, however, and their ensuing psychological disintegration exposes their attempted composure as unattainable; their world of make-believe is fragmented into a cluster of private hells which would remain all too real( p.579).

It comes as no surprise that Tartt admits in an interview to being fascinated by "the striking discrepancy between appearance and reality" manifested especially in Victorian murder stories (Hunnewell 1992:3). In fact, on at least one occasion an intertextual echo of this fascination surfaces in the fictional world of her novel: when Francis finds reason to include in his bibliophile shopping list "a study of Victorian murderesses" (p.504). This reference, perhaps, reflects the interest of the authorial persona rather than being consistent with Francis' known literary preferences.

\subsection{Communication in Greek and Latin}

It is not customary for students of classical Greek to converse in that language, as Richard admits: "Ancient Greek is a difficult language, a very difficult language indeed, and it is eminently possible to study it all one's life and never be able to speak a word ..." (p.235). Nevertheless, Tartt's precocious characters fairly often intersperse their English with Greek or Latin words or phrases, or quotations from classical sources; at times they even conduct short conversations, or write notes, in Greek or Latin.53 Some of these phrases or quotations do not form part of the dialogue, but belong to the retrospective assessment of the narrator, Richard; at any rate, the only written or oral communication in Greek that appears to be spontaneous and more or less fluent, is that between Julian and his star pupil, Henry. 54

In assigning written or spoken Greek or Latin for communication purposes to her characters, Tartt employs various strategies. The following three occur most frequentiy: the introduction of quotations to enhance or validate the classical atmosphere; the use of disparaging remarks to reinforce a speaker's attitude of condescension; the use of brief phrases in private conversation as a code or metalanguage incomprehensible to outsiders eavesdropping.

\subsubsection{Quotations}

The interspersion of English narrative or conversation with a quotation from the Classics occurs fairly frequently. For instance, in describing the physical beauty of his new

53 The evaluation of Shapiro \& Sawhill (1992:54) is misleading: "The characters scatter classical Greek quotations accross their conversation like parsley." In fact, despite the frequency of quotations, the narrator more than once stresses the clumsiness of their Greek, and actually credits Bunny with "erudite misquotations" (p.265).

\$4 It should be bome in mind that Tartt's Greek is, by her own admission, not above suspicion. See p. 142 (Hunnewell). For Richard's admiration of Henry and Julian's mastery of the Greek language, see p.235: "Their reason, their very eyes and ears were fixed irrevocably in the confines of those stern and ancient rhythms ...." 
classmates, Richard resorts to a quotation from Vergil: "... they were magnificent creatures, such eyes, such hands, such looks - sic oculos, sic ille manus, sic ora ferebat" 55 (p.34). Later, he adopts the same strategy when attempting to articulate Julian's rose-tinted view of his elite students: "genis gratus, corpore glabellus, arte multiscius, et fortuna opulentus $^{56}$ - smooth-cheeked, soft-skinned, well-educated, and rich" (p.382).

Inspecting a property in the Hampden countryside with a view to purchasing it, Henry is reminded of his preference for landlocked places instead of the sea. In this, he maintains, he resembles the Arcadians as depicted by Homer: "With ships they had nothing to do" (p.244). $57 \mathrm{He}$ prefers the mysteries of the mountains, he admits, to the monotony of the plains of Troy: "'Pan himself was born in the mountains, you know. And Zeus. In Parrhasia it was that Rheia bore thee', he said dreamily, lapsing into Greek, 'where was a hill sheltered with the thickest brush'" (p.244). Henry's preference for hilly country is surely no coincidence: it reminds one of Bacchic rituals, whether in Thebes or in Vermont.

When Charles expresses his remorse about the misery they have inflicted on Bunny's

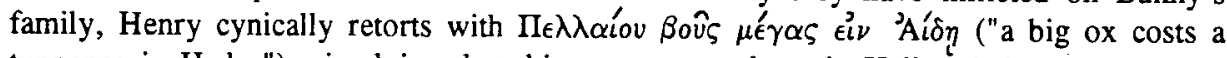
tuppence in Hades") - implying that things are very cheap in Hell and that Bunny, as a miser, will thus be happy there (p.371). On a more sombre note, Henry's letter to Richard, in which the latter is invited to attend Bunny's funeral, is concluded with these epic lines:

"Be strong, saith my heart; I am a soldier;

I have seen worse sights than this" (p.454).58

When the inexperienced Dick Spence takes over Julian's classes after the latter's resignation, Henry is so annoyed with Spence's mediocrity that he addresses him, sarcastically, in Attic Greek: "Without your patience, my excellent friend, we should wallow in ignorance like a sty full of pigs" (p.616). The point is that this would be beyond Spence's comprehension.

Finally, taking leave of Camilla, Richard is reminded of Orpheus looking back at the unattainable Eurydice, and quotes hinc illae lacrimaes9 to give expression to his emotions (p.655).

In the case of three further examples, quotations are referred to only in vague terms: in response to Richard's honest answer, Julian quotes "a little Greek epigram about honesty being a dangerous virtue" (p.29); Julian invites the twins to confide in him by quoting an aphorism from Xenophon (p.182); after breakfast Julian quotes "some Horatian-sounding tag about meat being good for sorrow" (p.508).

55 The unacknowledged source is Aeneid 3:490. The discrepancy between the plural verb in English and the singular verb in Latin is clumsy.

Once again, Tart should have adapted her English subject to agree with the singular number of the adjectives in the Latin original (Minucius Felix 2, 34 quoted by Martianus Capella).

57 The unacknowledged source is Iliad 2. 614.

58 The quotation is erroneously attributed to lliad 11, where Odysseus, cut off from his friends, finds himself on enemy territory. A comparable passage occurs in Od. 20.18 (quoted in Rep. 390 D).

59 The unacknowledged source is Terence, Andria i.99 (hinc illae lacrimae ... haec illa est misericordia), later quoted in part by Horace (Epistulae Bk. 1. 19.41). 
These examples demonstrate to what use Tartt puts Greek and Latin quotations. While they can hardly be called indispensable, they do fulfil the function of validating, or enhancing, the classical basis of Tartt's novel by adding point to the characters' observations.

\subsubsection{Hauteur}

Sometimes Tartt's characters speak Greek or Latin to convey their imagined intellectual superiority. For example, when Richard approaches his first class as a newcomer, Bunny disparagingly addresses him: "Are you the new neanias?", followed by "Cubitum eamus?", probably in order to expose Richard's incompetence in Latin (p.36). Shortly afterwards (p.39) Richard is cross-examined about his expertise by a supercilious Henry, who says something rapidly in Latin. Richard, of course, is out of his depth. These two examples serve to highlight the arrogance of Henry and his clique right from the outset, and also to demonstrate how they initially aim at perpetuating Richard's ostracism or marginalization.

Later Bunny, feeling resentful about his omission from his friends' Bacchanalia, attempts to take revenge by pointing snide and embarrassing remarks like "Khairei,60 deerslayers!" (p.213) and "Feeling queasy, bakchoi?" (p.214) at them. The point of these remarks is not simply to highlight Bunny's forte for radiating hauteur (which is made explicit in a variety of passages), but to expose his puerile schadenfreude at the possibility of betraying their secret. For once, he possesses knowledge with more bargaining power than theirs.

Two further instances of Greek being used to denote condescension, occur: one has already been mentioned in a different context (p.616); in the other, the vaunted superiority is contemplated rather than expressed.61

Thus it can be inferred that classical Greek or Latin, on account of its potential for being regarded as elitist, is sometimes used by a speaker with the perception that its use confers status $\mathrm{cn}$ him and exposes the cerebrally lower standing of his "less educated" hearer.

\subsubsection{Metalanguage}

Shortly before Bunny's death, Charles jealously discovers that Henry and Camilla are employing a secret telephone code to dial each other (p.293). Much more intriguing, however, is the students' use of a linguistic code: Greek or Latin spoken or written with a view to excluding non-cognoscenti and thus safeguarding the privacy of the conspirators.

For example, when Richard becomes increasingly suspicious about the mystifying behaviour of the others (in preparation for their Dionysiac experiment, as he later deduces), he notices them using "asides in Greek or even Latin which ... were meant to go over my head" (p.105). Again, on his return from Italy, Henry tells Richard how Bunny used to embarrass him in the course of their tour. While Henry was ill, Bunny was surreptitiously trying to read his diary, kept in Latin, in which the term used for Bunny was the taxonomically correct but unflattering epithet cuniculus molestus. Even Bunny

60 Should the less than perfect Greek of the implicit author or that of the erratic Bunny be held responsible for the flawed singular imperative?

61 Richard, asked for a financial contribution to a party by "a couple of Neanderthals" (p.171), tacitly looks down on them as "hoi polloi" and "barbaroi" (p.172) - a not un-Greek sentiment towards outsiders. Henry's disdain for hoi polloi is also mentioned later (p.246). For a recent examination of the barbaros topos, see Cartledge 1993:36-62. 
could conceivably have deciphered this with the aid of a dictionary. Having broken the code, Bunny also became privy to the secret of the manslaughter (pp.222-223).

Lodging at the Corcorans, in the days preceding Bunny's funeral, Francis employs the stratagem of speaking "sloppily inflected" Greek to Richard, in order to thwart possible eavesdroppers (pp.451-452). The gist of Francis' remarks is that Bunny's mother is concerned about the possibility of her son having been inebriated at the time of his death,

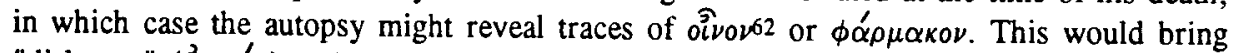
"dishonor" ( $\left.\alpha^{2} \tau \iota \mu^{\prime} \alpha\right)$ and "shame" to his family. Richard corrects Francis by pointing out that $\dot{\alpha} \tau \mu \mu^{\prime} \alpha$ ("loss of civil rights") applies to the living, not the dead.

Minor examples of Greek employed as a metalanguage include the following: when a local newspaper report fails to link her brother Charles to the missing Bunny, Camilla says "Thank God" in Greek (p.378); while drinking at the Farmer's Inn, Richard has to caution the drunken Charles, in Greek, against speaking within earshot of the barmaid (p.432); after Richard and Cloke have discovered huge quantities of barbiturates and amphetamines in the vanity case of Bunny's grandmother, Francis resorts to Greek when asking Richard whether he has drugs (p.476); Francis, arriving to inform Richard that Camilla and Henry have moved into the Albemarle Inn, announces in Greek (in order to by-pass Sophie Dearbold): "Important news, my friend" (p.552).

Other less frequent usages of Latin or Greek phrases include the following: summary statements or formal greetings in Latin; 63 well- known Latin phrases comprehensible to the educated non-classicist; 64 and Greek or Latin used in creative conversation spiced with repartee. 65

The above examples demonstrate that classical Greek can be used as a secret language, even if hampered by the inability of the conspiratorial speakers to formulate long sentences. In one instance, however, the limitations of this code are painfully exposed. After Julian has received Bunny's letter but not yet recognized its authenticity, Richard realizes that Julian is the single person they cannot fool with their "secret" code: "Always, previously, in an emergency we could throw out something in Greek, under the guise of an aphorism or a quotation. But now that was impossible" (p.593). Thus the wheel has turned full circle: the four surviving members of the Classics clique, who once sought to effect Richard's exclusion by means of their highbrow code, are now themselves excluded, together with Richard, by someone better able to utilize the very code once conferring privileged status on them. Julian, the only remaining insider, ostensibly departs for nevernever-land, 66 while his five students become outsiders, exiled to the stringent confines of reality.

62 Although there is nothing in the context to warrant an accusative, the form olvov is used. The narrator has, however, warned the reader that Francis is employing "sloppily inflected Greek".

consummatum est (John 19:30) (pp.115, 324); deprendi miserum est (p.202); salve, amice, ... valesne? (p.508).

64 E.g. quod erat demonstrandum (p.7); arrectis auribus (p.229); requiescat in pace (p.259); amor vincit omnia (Vergil) (p.263); nihil sub sole novum (cf. nil novi sub sole: Ecclesiastes 1:9) (pp.348, 355); et tu, Brute (p.514).

65 Not surprisingly, such conversations are restricted to Julian and Henry (pp.235-236, 508), who approach their dialogues as homines ludentes. This is but a logical consequence of Julian's Aristotelian view that learning is fun (pp.35-36).

66 Suaoriland ("somewhere in East Africa", p.657) represents one of Tartt's few ventures into fictitious geography, the other example being that of the "terrorist state" Isrami (pp.411-412, 610). 


\section{ADDENDUM 1}

On the whole, literary works are alluded to by title, by author, by character(s), or by quotation (acknowledged or unacknowledged).

Expressed in terms of authors, the list includes the following: Nietzsche (before Prologue); Tolkien (p.6); Milton (pp.8, 71, 488); Ezra Pound (p.17); Racine (p.20); Philip Roth (p.34); Dante (pp.34, 43, 84, 121, 194, 275, 277, 397, 414, 561, 658); Sylvia Plath (p.63); F. Scott Fitzgerald (p.82); Sir Walter Scott (pp.89, 294); Byron (p.89); T.S. Eliot (pp.17, 93-94, 149; 243, unacknowledged); Milton (p.95); Flaubert (p.99); St. Simon, Pope (p.108); Thackeray (p.116); Dorothy Sayers (p.121), John Donne (p.123); Izaak Walton (p.126); Rupert Brooke (p.126); H.G. Wells (p.137); Poe (pp.139, 209); Hegel (p.146); the Sitwells (p.149); Borges (p.170); Dickens (pp.189, 235, 649); Voltaire (p.230); Melville (p.235); Shakespeare (pp.54, 235, 626, 646); Conan Doyle (pp.269, 653); Rimbaud (pp.270; 5, 647, unacknowledged); Gertrude Stein (p.282); Charles Jackson (p.348); Dostoyevsky (pp.364; 468, unacknowledged); Cocteau (p.393); Tolstoy (pp.400, 599); Theophile Gautier (p.425); the Upanishads (pp.462, 488); John McCrae (p.488, unacknowledged); Tennyson (p.488); Housman (pp.488-489); Sartre (p.496, unacknowledged, and perhaps unintended); Proust (pp.501, 642); George Sand (p.501); Cortés, Gregory of Tours (p.504); R.L. Stevenson (pp.517, 624); Aquinas (p.533); Sterne, Defoe, Marx, Castaneda (p.545); Swift (p.557), Wodehouse (p.564); John Suckling (p.576, unacknowledged); Lewis Carroll (p.581); Kipling (p.594); Orwell (p.605); Rushdie (p.610); Agatha Christie (p.615); John Ford (pp.639, 645); Marlowe, Webster, Middleton, Tourneur (pp.645-646); Sir Walter Raleigh, Thomas Nashe (p.646).

\section{ADDENDUM 2}

This is the single category of literary allusions employed most frequently. The reader's acquaintance with the original author or literary character is mostly required for proper comprehension of the comparison. Thus, adjectives and phrases like "Dantesque" (pp.84, 397, 414, 658), "Poe-like" (pp.139, 209), "these Dostoyevsky sort of ideas" (p.364), or "kind of a Jean Cocteau touch" (p.393), denote an atmosphere that is grotesque, eerie, sinister or morbid, while "like something from Tolstoy" (p.400) reminds one of snowy expanses. Other examples: "... a lowbrow pop-psychology version of Sylvia Plath" (Richard's ex-girlfriend, p.63); Richard sees tragic similarities between Jay Gatsby and himself (p.82); Bunny claims (fallaciously) that he experienced "a manifestation of early genius, like Alexander Pope" (p.108); Charles attempts to emulate the piquet-playing Rawdon Crawley in Vanity Fair (p.116); "like the Invisible Man in H.G. Wells" (Richard's alienation in his solitary winter at Hampden, p.137); "very thistly and childish, d la Arthur Rimbaud" (the result of Richard's tonsorial experiment, pp.269-270); "like something from Sir Walter Scott" (the idea of poisoned mushrooms, p.294); "like one of those old Florentines Dante meets in Purgatory" (F.B.I. agent Sciola, p.414); "like Lilliputians round the sleeping Gulliver" (nursery-school children imagined as huddling round the hung-over Charles, p.557); "like some crazed gardener from Alice in Wonderland" (Henry polishing the leaves of a rosebush, p.581); "looking out the window like the old pirate in Treasure Island" (Charles, inebriated, p.624); "like Sherlock Holmes. Going over the Reichenbach Falls" (Francis on Henry's suicide, p.653). 


\section{BIBLIOGRAPHY}

Allan, B. 1992. "Panpipes and Preppies." The New Criterion XI, October, 65-68.

Beal, G. \& Grisewood, J. 1990. Factbook of the 20th Century. Milan: Vallardi.

Brink, A.P. 1987. Vertelkunde. 'n Inleiding tot die lees van verhalende tekste. Pretoria: Academica.

Cartledge, P. 1993. The Greeks. A portrait of self and others. Oxford: Oxford University Press.

Cilliers, L. 1986a. Genresisteme in die klassieke letterkunde en die nawerking daarvan in die westerse letterkunde. Bloemfontein: U.O.V.S. (Intreerede).

Corry, L. 1992. "Jorge Borges, Author of The Name of the Rose." Poetics Today 13, 425445.

De Jong, I.J.F. 1987. Narrators and Focalizers. The presentation of the story in the lliad. Amsterdam: Grüner.

Dodds, E.R. 1973. The Greeks and the irrational. Los Angeles: University of California Press.

Foster, P.H. 1994. "'Want hy monitor op 'n skerm': Skrywer en rekenaar." Stilet 6, 111122.

Genette, G. 1981. "Theorieën van literaire genres: inleiding in de architeks", pp.61-120 in Bal, M. (red.), Literaire genres en hun gebruik. Muiderberg: Coutinho.

Green, J. 1993. New Words and their Meanings. Reading, Berkshire: Parragon Press.

Highet, G. 1967. The Classical Tradition. Oxford: Oxford University Press.

Hunnewell, S. 1992. "Her duty is to fool the reader." The New York Times Book Review, September 13, 3 .

Kaplan, J. 1992. "Smart Tartt." Vanity Fair 55, September, 248, 250-251, 276-278.

Lescaze, L. 1992. "Groves of Academe Shed Gold and Yawns." The Wall Street Journal, September 9, A12.

Rosenheim, A. 1992. "Dead guy on campus." The New York Times Book Review, September 13, 9 .

Segal, C. 1986. "Greek Tragedy and Society: A Structuralist Perspective", pp.43-75 in Euben, J.P. Greek tragedy and political theory. California: California University Press.

Shapiro, L. \& Sawhill, R. 1992. "Anatomy of a Hype." Newsweek vol. CXX no. 10, September 7, 54-55.

Smyth, H.W. 1956. Greek Grammar. Cambridge, Mass.: Harvard University Press.

Steinz, P. 1992. "Hoogmoed in Vermont." Cultureel Supplement N.R.C. Handelsblad, 30 Oktober, 1 .

Steinz, P. 1994. Review of John Irving's A Son of the Circus. Cultureel Supplement N.R.C. Handelsblad, 5 Augustus, 3. 
Tartt, D. 1993. The Secret History. Harmondsworth: Penguin Books.

Vaill, A. 1992. "Beyond Good and Evil." Book World - The Washington Post, September $13,3,9$.

Van Boheemen, C. 1981. "Intertekstualiteit", pp.121-130 in Bal, M. (red.), Literaire genres en hun gebruik. Muiderberg: Coutinho.

Viljoen, H. 1988. "Spieël, kamer van spieëls: oor postmodernisme en representasie." SAVAL Kongresreferate VIII, 351-363.

(to be continued) 